PPPL-3020

UC-420,423,424,425

PPPL-3020

\title{
MEASUREMENTS OF TFTR D-T RADIATION SHIELDING EFFICIENCY
}

\author{
BY
}

H.W. KUGEL, G. ASCIONE, S. ELWOOD, ET AL.

NOVEMBER 1994

\section{MASTER}

DISTRIBUTION OF THIS DOCUMENT IS UNLIMITED $\left.\left.\int \frac{D}{5}\right] \frac{D}{5}\right] \int \begin{aligned} & \text { PAINCETON } \\ & \text { PLASMA PHYYSICS } \\ & \text { LABORATORY }\end{aligned}$

y

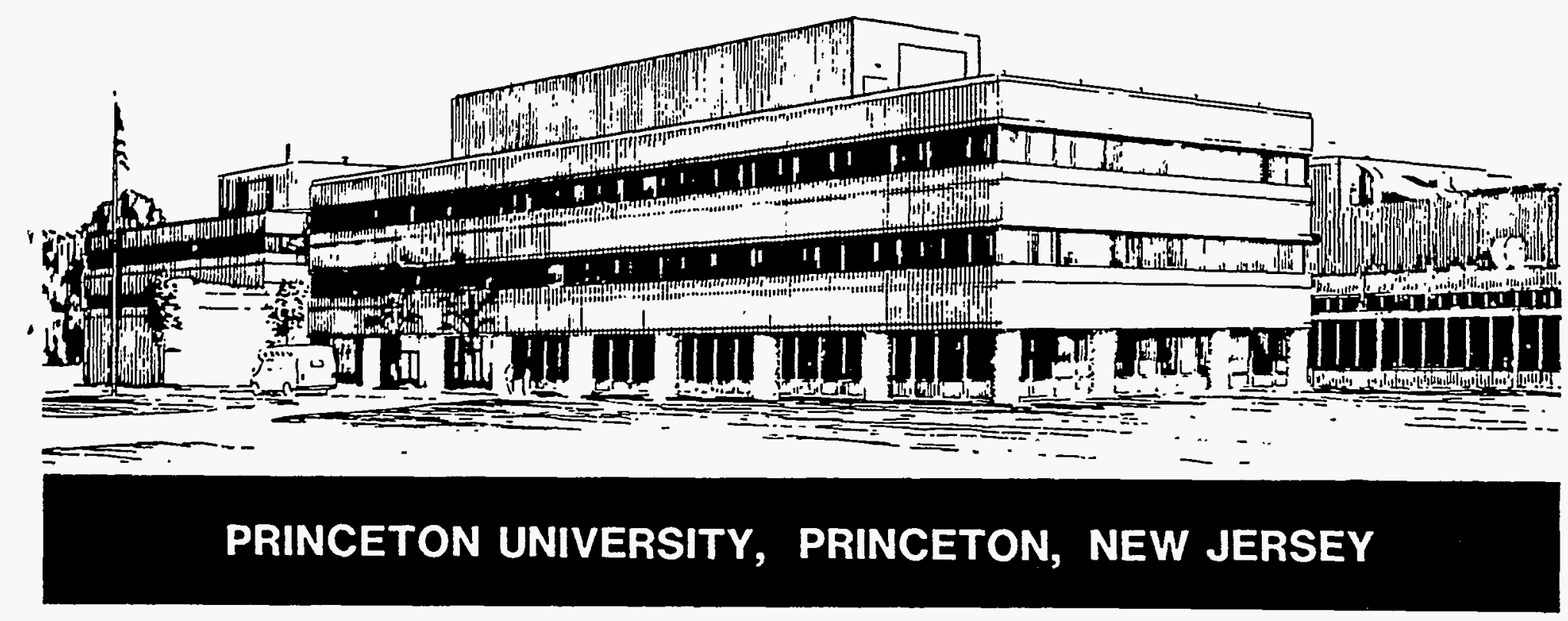




\section{NOTICE}

This report was prepared as an account of work sponsored by an agency of the United States Government. Neither the United States Government nor any agency thereof, nor any of their employees, makes any warranty, express or implied, or assumes any legal liability or responsibility for the accuracy, completeness, or usefulness of any information, apparatus, product, or process disclosed, or represents that its use would not infringe privately owned rights. Reference herein to any specific commercial produce, process, or service by trade name, trademark, manufacturer, or otherwise, does not necessarily constitute or imply its endorsement, recommendation, or favoring by the United States Government or any agency thereof. The views and opinions of authors expressed herein do not necessarily state or reflect those of the United States Government or any agency thereof.

\section{NOTICE}

This report has been reproduced from the best available copy. Available in paper copy and microfiche.

Number of pages in this report: 27

DOE and DOE contractors can obtain copies of this report from:

Office of Scientific and Technical Information

P.O. Box 62

Oak Ridge, TN 37831;

(615) 576-8401.

This report is publicly available from the:

National Technical Information Service

Department of Commerce

5285 Port Royal Road

Springfield, Virginia 22161

(703) $487-4650$ 


\section{DISCLAIMER}

Portions of this document may be illegible in electronic image products. Images are produced from the best available original document. 


\section{Measurements of TFTR D-T Radiation Shielding Efficiency}

H. W. Kugel, G. Ascione, S. Elwood, J. Gilbert, L.-P. Ku, J. Levine, and K. Rule

Princeton Plasma Physics Laboratory, Princeton University

P. O. Box 451, Princeton, NJ 08543

N. Azziz, P. Goldhagen, F. Hajnal, and P. Shebell

U.S. DOE Environmental Measurements Laboratory

New York, NY 10014-3621

\section{Abstract}

Measurements of neutron and gamma dose-equivalents were performed in the Test Cell, at the outer Test Cell wall, in nearby work areas, and out to the nearest property lines at a distance of $180 \mathrm{~m}$. Argon ionization chambers, moderated ${ }^{3} \mathrm{He}$ proportional counters, and fission chamber detectors were used to obtain measurements of neutron and gamma dose-equivalents per D-T neutron during individual TFTR discharges. These measured neutron and gamma D-T doseequivalents per TFTR neutron characterize the effects of local variations in material density resulting from the complex asymmetric site geometry. The measured doseequivalents per TFTR D-T neutron and the cumulative neutron production were used to determine that the planned annual TFTR neutron production of $1 \times 10^{21} \mathrm{D}-\mathrm{T}$ neutrons is consistent with the design objective of limiting the total dose-equivalent at the property line, from all radiation sources and pathways, to less than 10 mrem per year. 


\section{Introduction}

Recent Tokamak Fusion Test Reactor (TFTR) deuterium (D) - tritium (T) experiments have provided the first opportunity to study fusion reactor radiological shielding issues with a high power fusion neutron source in a reactor-like environment [1, 2]. High power D-T fusion reactor designs presently exhibit complex asymmetric geometric and material density configurations. Simulations of the radiation shielding required for safe operation and full compliance with all regulatory requirements must include sufficient design margin to accommodate uncertainties in material properties and distributions, uncertainties in the final configurations, and uncertainties in approximations employing the homogenization of complex geometries. Measurements of radiation shielding efficiency performed in a realistic $D$ $T$ tokamak environment can provide empirical guidance for simulating safe, efficient, and cost effective shielding systems for future high power fusion reactors.

In this work, we present the results of initial measurements of the TFTR radiation shielding efficiency during high power D-T operations with record neutron yields. The TFTR experimental plan is to produce $1 \times 10^{21} \mathrm{D}-\mathrm{T}$ neutrons per calendar year and the design objective is to limit the total dose-equivalent at the nearest property lines from all radiation pathways to 10 mrem per year. Thorough compliance with this design objective involves radiation measurements of each TFTR plasma discharge in the presence of typical site backgrounds of about $80 \mathrm{mrem}$ per year. The radiation pathways are the prompt contributions from direct transmission through inefficiencies in the shielding, prompt contributions from sky, ground, ceiling, and wall reflections, and delayed contributions from the dispersal of activated air, liquid nitrogen, and normal tritium leakage.

\section{Experimental geometry and conditions}

Fig. 1 shows a partial schematic plan view of the TFTR Test Cell which has dimensions of about $46 \mathrm{~m} \times 35 \mathrm{~m} \times 18 \mathrm{~m}$ high. The floor is $0.91 \mathrm{~m}$ thick concrete of which $0.3 \mathrm{~m}$ is borated limestone aggregate type concrete. The vessel is located over a $1.83 \mathrm{~m}$ thick borated concrete platform designed to support the loads of the tokamak system. Penetrations in the floor are provided for the access to the vessel for the coil leads, mechanical piping, and diagnostic equipment. Wherever possible, shielding plugs are used to reduce streaming through the penetrations. The roof of the Test Cell is mostly $1.30 \mathrm{~m}$ of ordinary concrete except directly over the vessel where it is $1.68 \mathrm{~m}$ 
thick. The walls are $1.2 \mathrm{~m}$ of ordinary concrete. The interior walls are clad with $0.3 \mathrm{~m}$ thick supplementary concrete shielding panels $1.52 \mathrm{~m}$ wide by $7.32 \mathrm{~m}$ high and attached to the wall with bolts. In addition, $1.82 \mathrm{~m}$ inward from the north wall, a $0.3 \mathrm{~m}$ thick supplementary concrete shielding wall $8.2 \mathrm{~m}$ high spans most of the north wall. The Test Cell walls are penetrated by an equipment door, three personnel labyrinths and several $15.2 \mathrm{~cm} \mathrm{I.D.} \mathrm{holes} \mathrm{in} \mathrm{the} \mathrm{north,} \mathrm{east,} \mathrm{and} \mathrm{south,} \mathrm{walls} \mathrm{for} \mathrm{diagnostic}$ equipment. Four large neutral beam injection systems and other high density Test Cell hardware provide additional shielding in the southward and westward directions. Fig. 2 shows a partial schematic plan view of the TFTR site. Shown are the nearest buildings, the site-fence at $125 \mathrm{~m}$, the nearest property lines at $180 \mathrm{~m}$, and the locations of the stationary detectors of the radiation monitoring system. Directions eastward from the Test Cell receive additional shielding from the $1.2 \mathrm{~m}$ thick concrete east wall of the Hot Cell.

The initial TFTR D-T experiments [1, 2] were performed in an enhanced confinement regime characterized by peaked plasma density profiles. The toroidal field was 5.0 T and the plasma current was 2.0 MA. The plasma major radius for these experiments was $2.52 \mathrm{~m}$ and the minor radius of the circular cross-section plasmas was $0.87 \mathrm{~m}$. D and T neutral beams were injected with energies of 90-107 keV to heat and fuel the discharge. Plasma current discharge pulse lengths were typically $4.0 \mathrm{sec}$. $D$ neutral beams were $1 \mathrm{sec}$ in duration and $T$ beams were $0.75 \mathrm{sec}$ in duration. Neutral beam injection was initiated $3.0 \mathrm{sec}$ after the start of the plasma current. The discharge repetition time was $15 \mathrm{~min}$. Typically, D-D discharges were produced before, between, and after D-T discharges for conditioning, set-up, or fiducial purposes. Peak D-T fusion powers of up to $9 \mathrm{MW}$ were produced with neutral beam heating of over $33 \mathrm{MW}$. Under these conditions, the emission rate for $14.1 \mathrm{MeV}$ neutrons was over $2 \times 10^{18} \mathrm{sec}^{-1}$. During D-D discharges, the emission rate was typically in the range $1-4 \times 10^{16} \mathrm{sec}^{-1}$. The experiments included varying the neutral beam power in tritium from about 10 to $100 \%$. The results presented in this work were measured during discharges in which the yield of $14.1 \mathrm{MeV}$ neutrons from $D-T$ reactions exceeded the yield of $2.5 \mathrm{MeV}$ neutrons from $\mathrm{D}-\mathrm{D}$ reactions by factors in the range from about 10 to 100 . 


\section{Experimental procedure}

The TFTR radiation monitoring system included 14 pairs of stationary neutron and gamma detectors connected to an automatic data acquisition system. The detected radiation from each discharge and background measurements performed at 15 minutes intervals were archived automatically. The stationary detector sets were located as follows; four outside the TFTR Test Cell wall, one centered on the roof above TFTR, four at the site-fence, and two at the nearest property lines (Fig.s 1 and 2).

The neutron detectors were mostly ${ }^{3} \mathrm{He}$ proportional counters moderated with $25 \mathrm{~cm}$ polyethylene spheres with a lower limit of detection of 6 nanorem/pulse. At selected higher intensity locations, moderated $25 \mathrm{~cm}$ Bonner sphere Lil(Eu) detectors and $235 \mathrm{U}$ fission chamber detectors were used for neutron detection. The gamma detectors were pulse compensated pressurized ionization chambers. These were environmental-type gamma detectors of two types; high-rate with a useful range of $1000 \mathrm{mR} / \mathrm{hr}$, and low-rate with a useful range of $2000 \mathrm{microR} / \mathrm{hr}$. The lower limit of detection for the high sensitivity (low-rate) gamma detectors required in far field regions, near the site-fence and at the property lines was 1 nanorem/pulse.

In addition to these stationary electronic detector systems, large arrays of vendor calibrated ${ }^{7}$ LiF thermoluminescent dosimeters (TLD), gamma film badges and neutron etch track and film badges were deployed extensively to monitor personnel and equipment radiation exposures.

Portable gamma dose-equivalent measurements were made at many remote locations out to the property lines at a major radius of $180 \mathrm{~m}$ using either the high-rate or the low-rate pressurized ionization chambers as required. The low-rate detectors had a lower limit of detection of 1 nanorem/count. Portable neutron dose-equivalent measurements were made at the same remote locations using a ${ }^{3} \mathrm{He}$ proportional counter moderated with a $25 \mathrm{~cm}$ polyethylene sphere and having a lower limit of detection of 4.6 nanorem/count.

The TFTR radiation detectors were calibrated in a special PPPL laboratory dedicated to the calibration of health physics detectors using sources which are traceable to the National Institute of Standards and Technology (NIST). All calibration and testing procedures were in compliance with the American National Standards Institute (ANSI) standard N323, "Radiation Protection Instrumentation Test and Calibrations", in addition to vendor technical manuals and procedures. A ${ }^{137} \mathrm{Cs}$ source was used for radiation response and acceptance criteria for the gamma detectors, and 
a $238 \mathrm{Pu} / \mathrm{Be}$ source was used for the neutron detectors. Check sources were used in the field to verify radiation response and accuracy at appropriate intervals.

The possibility of electronic detector counting losses during high D-T neutron yield pulses was monitored very carefully, and avoided wherever possible, using the procedures described below. During D-T operations, the neutron and gamma dose rates resulting from these pulses varied over a range of at least $10^{5}$ from locations in the Test Cell basement and adjoining areas, to around the Test Cell walls, and out to the $180 \mathrm{~m}$ property lines. At locations in the Test Cell Basement and adjoining areas, the dose rates were sufficiently high to cause electronic radiation detectors to undergo severe counting losses or saturation. In these areas, other types of radiation detectors, e.g. special etch track detectors and TLD's also were employed. This work is still in progress and is not reported in this paper. At locations at ground level from the Test Cell outer walls and out to the $180 \mathrm{~m}$ property lines, the dose rates were much lower, and within the useful linear range of the selected detectors. The high dose rate gamma detectors, for example, could be used reliably at the Test Cell outer walls, whereas in the far field region, the low dose-rate detectors were required to detect the very low signals. At locations with intermediate dose-rates, both high-rate and low-rate detectors were often employed for a consistency verification. In the case of the neutron detectors, some locations did exhibit dose-equivalent rates requiring standard, first order, count rate corrections using actual measured "dead-times". In this paper, all of the reported neutron and gamma measurements, with two exceptions, were performed at locations at which measured dose rates were within the linear range of the detectors and did not require count rate corrections. The two exceptions were the measurements at the east and south outer walls of the Test Cell where nearby shielding penetrations caused increased fields. At these locations, as well as, all of the measurement regions discussed in this paper, least-squares-fits of the measured dose-equivalents to the TFTR neutron yields clearly exhibited either a linear response for the respective detectors, or the need for counting loss corrections. The data to perform these least-square-fits was acquired routinely since a typical D-T experimental day included both relatively lower neutron yield D-D discharges and D-T discharges exhibiting a wide range of neutron yields. This least-squares-fitting analysis was also used to advantage as discussed below.

The dose-equivalents per TFTR pulse measured at a particular location were normalized to the total number of TFTR D-T neutrons per pulse to obtain the doseequivalent per TFTR D-T neutron. The measured total TFTR D-T neutrons were obtained from the precision research neutron detection systems at the tokamak for 
determining the fusion power yield to within typical uncertainties of $\leq \pm 15 \%$. Leastsquares-fittings of the measured total number of TFTR neutrons at the tokamak with dose-equivalent measurements made at various locations yielded the dose-equivalent per TFTR neutron for those locations. These ratios characterize a particular location and exhibit the effects of local variations in material density resulting from the complex site geometry. Hence, this least-squares-fitting analysis procedure provided a measure of the linear response of the detectors, demonstrated the direct proportionality of the measured radiation field at each location, and yielded a relatively accurate measure of the mrem per source neutron.

\section{Radiation measured during D-T operations}

The measured results are presented below starting with the locations closest to TFTR at the inside Test Cell wall, at the Test Cell outer walls, and proceeding to the farthest locations at a major radius of $180 \mathrm{~m}$.

\subsection{TFTR Test Cell}

A special $\mathrm{Al}_{2} \mathrm{O}_{3}$ thermoluminescent dosimeter method described previously [3] was used to measure the gamma dose at the Test Cell inner east wall on the midplane of TFTR (3.3 $\mathrm{m}$ above floor) at $R=24 \mathrm{~m}$. The measured gamma dose per TFTR D-T neutron was $3.2 \pm 0.7 \times 10^{-15}$ mrem per $D-T$ neutron. A value of the gamma dose per $D$ $D$ neutron is unavailable for this east wall location. However, measurements at 2 midplane locations at the opposite west wall gave an average of $3.5 \times 10^{-15} \mathrm{mrem}$ per $D-D$ neutron [4]. Using this value gives a gamma D-T to D-D dose ratio of 0.91 which is of order the simulation result at the inner walls [5]. Neutron dose-equivalent measurements using activation foils on the Test Cell walls are in progress and preliminary results will be reported elsewhere [6].

\subsection{TFTR Test Cell outer walls}

Neutron dose-equivalent measurements per TFTR D-T neutron were performed at the outer walls of the Test Cell, at the indicated north, east, south, and west locations (Fig.1), at an elevation $3.3 \mathrm{~m}$ above the floor, corresponding to the mid-plane of TFTR. Table 1 summarizes the results. The lowest external fields are at the north wall. This is 
attributed to the additional $30 \mathrm{~cm}$ of concrete supplementary shielding which reduced the neutron field significantly in the northward direction (Fig.1). The highest fields were measured at the outer east wall which has the least nearby Test Cell hardware, and has five penetrations for diagnostic instrumentation. Comparable but less intense fields were measured at the south and west outer walls where attenuation due to massive neutral beam line structures provided additional effective shielding. Directly over TFTR, at roof center, the field was in the range of those measured at the outer walls but decreased by $63 \%$ at a major radius of $17 \mathrm{~m}$. The radiation field incident on the Test Cell ceiling, however, must decrease more rapidly than implied by the roof measurements, since the concrete roof thickness at the center directly over TFTR is $1.68 \mathrm{~m}$ and decreases in a tapered manner to a thickness of $1.30 \mathrm{~m}$ at the roof edge. Fig. 3 shows a measured neutron dose-equivalents versus $D-T$ neutron for the two locations. It is seem that, at each location, the measured dose-equivalents are directly proportional to the neutron source strength consistent with what is usually assumed in shielding calculations.

The Table 1 also lists the neutron and gamma dose-equivalents per D-D neutron measured prior to the start of D-T operations [4]. It is seen that the ratio of the neutron $D-T$ dose-equivalent to the neutron $D-D$ dose-equivalent varies in the range from about 2 to 37 depending on the local material densities and shielding wall efficiencies. A simulation found an average value of order 20 for the outer Test Cell walls with significant variations due to changes in local material density [5]. The north wall with a ratio of 2 is in the direction of the greatest concrete shielding thickness (Fig. 1). The south and west walls have ratios of about 20 and 37, respectively, although the attenuation due to the neutral beamline geometry inside the Test Cell is similar. This higher ratio for the west wall is attributed in part to the lower shielding efficiency of the west wall which is not solid concrete, as are the other walls, but was fabricated from a double row of individual blocks of concrete with mortar and steel rod in the gaps between blocks. This trend in the neutron dose-equivalent ratios is also evident in the results measured at far distances given below. The available gamma dose ratios vary from 1.4 to 2.1. A simulation found an average value of order 2 and a relative insensitivity to the local material density distribution [5]. The behavior of the neutron and gamma dose-equivalents at these locations are still under investigation. 


\subsection{Radial dependence in the northeastward direction}

Neutron and gamma dose-equivalent measurements per TFTR D-T neutron were performed in the northeast ward direction toward the nearest property line. Fig. 4 shows a log-log plot of the results. It is seen that at closer distances, the neutron and gamma dose-equivalent results are comparable to within present experimental uncertainties, but at the farthest distances, the neutron dose-equivalent appears to be trending higher than that of the gamma dose. An inflection in slope appears to occur for locations beyond $50 \mathrm{~m}$ which correspond to measurements made outdoors beyond the Mockup building (Fig.2, directly north of the Test Cell). A least-squares-fit of the neutron results to a power law $(r n)$, from $19.5 \mathrm{~m}$ to $49.7 \mathrm{~m}$, gives an exponent of $n=$ -1.0. A least-squares-fit of the neutron results to a power law $(r n)$, from $70.2 m$ to 180 $m$, gives an exponent of $n=-3.6$. These results imply that reflections from the Test Cell ceiling, the Mockup Building ceiling, and nearby hardware may be contributing to the measured neutron fields at the nearer distances. Work is in progress to resolve these respective contributions.

\subsection{At the site-fence and the nearest property lines}

Fig.s 5 and 6 show the measured neutron and gamma dose-equivalents per TFTR D-T neutron in the northeastward direction at the site-fence at $R=125 \mathrm{~m}$, and at the property line at $R=180 \mathrm{~m}$. It is seem that, at each far field location, the measured dose-equivalents are directly proportional to the neutron source strength which is consistent to what is usually assumed in shielding calculations. Table 2 summarizes the far-field results. The lowest intensities at $R=125 \mathrm{~m}$ were measured in the southeastward direction. This is attributed to the effect of the extra $1.2 \mathrm{~m}$ of concrete shielding in that direction due to the Hot Cell walls (Fig. 2). The highest intensities at $R$ $=125 \mathrm{~m}$ were measured in the westward and northwestward directions where there was the least shielding. The effect of the extra $0.3 \mathrm{~m}$ concrete supplementary shielding along the Test Cell inner north wall (Fig.1) is seen in the northeastward site-fence and property line values which are comparable to those in the southeastward directions. Since, the total concrete shielding in the northeastward direction is $1.8 \mathrm{~m}$ and in the southeastward direction is $2.7 \mathrm{~m}$, these comparable property line intensities imply that the direct contribution through the walls is negligible and that the residual fields at the property lines are dominated by skyshine and upper building reflections. 
Table 2 also lists the neutron and gamma dose-equivalents per D-D neutron measurements prior to the start of D-T operations [4]. It is seen that the ratio of the neutron $D-T$ dose-equivalent to the neutron $D-D$ dose-equivalent varies in the range from about 1 to 5 depending on the local material densities and shielding wall efficiencies. The gamma dose-equivalent ratios are about 1 in the most efficiently shielded directions and about 2 in the less shielded westward direction. At far distances, in the northeastward direction, the additional attenuation provided by buildings and atmosphere appears to reduce the ratio of neutron $D-T$ to $D-D$ doseequivalents. A downshifting of the neutron energy spectrum due to these materials may also be responsible for the gamma dose being relatively higher than that due to the neutrons. Additional far field radiation measurements in other radial directions with different material configurations are in progress and may elucidate this behavior.

Fig. 7 shows a composite total gamma-ray energy spectrum for 12 TFTR D-T discharges measured using a high purity Ge gamma spectroscopy system at the location of the northeast site boundary fence detectors at $R=125 \mathrm{~m}$ (Fig.2). Each spectrum was corrected for dead time losses before being summed. The resulting spectrum was then smoothed using a 5 point sliding average. This spectrum includes the background contributions. This accounts for the small intensity at $1.460 \mathrm{MeV}$ from $40 \mathrm{~K}$. The energy calibration was checked periodically by noting the position of $40 \mathrm{~K}$ peak for ohmic discharges during which no neutrons were produced. Indicated are the full energy absorption for hydrogen (2.223 MeV) and for iron (7.631 and 7.645 $\mathrm{MeV}$ ). An unidentified peak exists at approximately $4.050 \mathrm{MeV}$. There is evidence of the $0.691 \mathrm{MeV}$ line intensity associated with the fast inelastic reaction in the germanium detector of $\mathrm{Ge}\left(n, n^{\prime} \gamma\right)$ for $E_{\text {neutron }}>0.5 \mathrm{MeV}$. There is however no evidence of the $0.596 \mathrm{MeV}$ line intensity associated with the interaction of thermal neutrons in germanium. Work is in progress to investigate the relative contributions from sources within the Test Cell and from materials in the shield wall and nearby hardware.

\section{Estimated Delayed Dose-equivalent contributions}

Table 3. shows the major air activation products estimated to be evacuated from the Test Cell during D-T operations are ${ }^{13} \mathrm{~N},{ }^{41} \mathrm{Ar},{ }^{40} \mathrm{Cl}, 37 \mathrm{~S}$, and relatively short-lived ${ }^{16} \mathrm{~N}$. The pacing activity is ${ }^{41} \mathrm{Ar}$ which may require a 5.2 hour exhaust time. The upper limit to the dose-equivalent due to activated air transported to the property line for a total annual yield of $1 \times 10^{21} \mathrm{D}-\mathrm{T}$ neutrons is estimated to be $0.73 \mathrm{mrem}$, if no ${ }^{16} \mathrm{~N}$ is exhausted and $2.5 \mathrm{mrem}$ if all $16 \mathrm{~N}$ is exhausted. These estimates were derived using 
the semi-infinite plume model with measured results from NOAA measurements at PPPL in which tracer gases were used to measure the atmospheric dilution factor, $x / Q$ $\left(1.77 \times 10^{-5} \mathrm{sec} / \mathrm{m}^{3}\right)$ [7-10]. The contribution of the $16 \mathrm{~N}$ activity to the property line is estimated to be negligible due to the long air recirculation time in the Test Cell and the net transport time.

Neutron induced activation of the liquid nitrogen $\left(\mathrm{LN}_{2}\right)$ in the cryopanels of the neutral beam injectors is estimated to produce about $15 \mathrm{mCi}$ of ${ }^{13} \mathrm{~N}$ per TFTR pulse per injector. This $L N_{2}$ is vented via an electrical heater to the vent stack. The property line dose-equivalent from activated $\mathrm{LN}_{2}$ after a yield of $1 \times 10^{21} \mathrm{D}-\mathrm{T}$ neutrons is estimated to be approximately 0.02 mrem using the same methodology described above for activated air.

The estimated upper limit to the annual tritium dose-equivalent released to the property line is taken to be no more than $1.3 \mathrm{mrem}$ per $500 \mathrm{Ci}$ vented to the atmosphere in the form of HTO which is estimated to be the maximum amount that could be released annually during normal operations using the same methodology described above for activated air.

\section{Annual property line total dose-equivalents}

Table 4 summarizes the contributions to the annual property line total doseequivalent of less than 2.4 mrem for an estimated annual yield of $1 \times 10^{21} \mathrm{D}-\mathrm{T}$ neutrons. The direct prompt neutron and gamma dose-equivalents contribute a total of about 0.32 mrem. The estimated activated air $(0.73 \mathrm{mrem})$ and the estimated normal tritium release $(<1.3 \mathrm{mrem})$ give the largest contributions to the total dose-equivalent. The actual dose-equivalent contributions from air activation and tritium release depend on many complex factors involving the meteorology during D-T experiments, the experimental sequence, and the maintenance procedures. Very sensitive measurements of Test Cell exhaust are in progress and the use of actual meteorological data could reduce these estimates.

\section{Summary and conclusions}

Measurements of neutron and gamma dose-equivalents were performed at the outer Test Cell walls, in nearby work areas, and out to the nearest property lines at a distance of $180 \mathrm{~m}$. Argon ionization chambers, moderated ${ }^{3} \mathrm{He}$ proportional counters, and fission chamber detectors were used to obtain measurements of neutron and 
gamma dose-equivalents per D-T neutron during individual TFTR pulses. Measured neutron and gamma D-T and D-D dose-equivalents for a given location were obtained and exhibit the effects of local variations in material density resulting from the complex site geometry. The contribution of the exhausted Test Cell activated air, liquid nitrogen, and natural tritium leakage were estimated. Measured dose-equivalents per D-T neutron were used to determine that the planned annual TFTR neutron production of 1 $x 10^{21} \mathrm{D}-\mathrm{T}$ neutrons is consistent with the design objective of limiting the total doseequivalent at the property line, from all radiation sources and pathways, to less than 10 mrem per year. The measurements also were used during TFTR D-T operations to monitor conditions, facilitate operational planning, and provide guidance for the development of high power fusion reactor shielding systems. These high power TFTR D-T radiation shielding measurements provide the first opportunity to study fusion reactor radiological shielding issues with a copious source of fusion neutrons in a reactor-like environment.

\section{Acknowledgments}

We wish to acknowledge the technical contributions of D. Birckbichler, K. Chase, R. Frankenfield, C. Szathmary, J. Lehner, M. Lewis, H. Murphy, and S. Williams. This work was supported by US Department of Energy Contract No. DEAC02-76-CHO-3073. 


\section{References}

[1] J. D. Strachan, H. Adler, P. Alling, C. Anchor, H. Anderson, et al., "Fusion Power Production from TFTR Plasmas Fueled with Deuterium and Tritium", Phys. Rev. Lett. 72, No. 22, (1994) 3526-3529.

[2] R. J. Hawryluk, H. Adler, P. Alling, C. Anchor, H. Anderson, et al., " Confinement and Heating of a Deuterium-Tritium Plasma", Phys. Rev. Lett. 72, No. 22, (1994) $3530-$ 3533.

[3] Nestor Azziz, Gladys Klemic, Richard Fried, and Juan Azorin, Nieto, " Measurement of Thermal Neutrons in Mixed $(n, \gamma)$ Fields Using $\mathrm{Al}_{2} \mathrm{O}_{3}$ TLDs", Nuc. Sci. J., 31, (1994) 59-63.

[4] H. W. Kugel, G. Ascione, S. Elwood, J. Gilbert, D. Hwang, et al., "TFTR Radiation Contour and Shielding Efficiency Measurements during D-D Operations", (to appear in the Proceedings of 11 Topical Meeting on the Technology of Fusion Energy", New Orleans, June 19-23, (1994).

[5] L. P. Ku and S. L. Liew, "A Semi-Empirical Algorithm for Determining Radiation Field Characteristics for TFTR", Proceedings of the 8th Int. Conf. on Radiation Shielding, Arlington, Texas, April 24-28, 1994, pp. 1062-1068.

[6] A. Kumar, M. A. Abdou, and H. W. Kugel, "Characterization of TFTR Shielding Penetrations of ITER-relevance in D-T Neutron Field", in the Proceedings of this Symposium.

[7] H. W. Kugel, C. W. Barnes, J. Gilbert, J. Greco, K. W. Hill, et al., "Measurements of TFTR Radiation Shielding During High Power D-D Operations", Fus. Technol. 19, (1991) 1989-1995.

[8] R. E. Moore, C. F. Baes III, L. M. McDowell-Boyer, A. P. Watson, F. O. Hoffman, "AIR DOSE-EPA: A Computerized methodology for Estimating Environmental Concentrations and Dose to Man from Airborne Releases of Radionuclides", Oak Ridge National Laboratory, Report No. ORNL-5532, June 1979, 270 p. 
[9] "Preliminary Radiological Assessment Report for TFTR", EBASCO Services Inc., EP-R-007, Feb., 1977.

[10] G. E. Start, C. R. Dickson, J. F. Sagendorf, G. R. Ackermann, K. L. Clawson, et al., "Atmospheric Diffusion for Airflows in the Vicinity of the James Forrestal Campus, Princeton University", U. S. Department of Commerce, National Oceanic and Atmospheric Administration, May 5, 1989. 


\section{Figure Captions}

Fig. 1. Partial schematic diagram of the TFTR Test Cell.

Fig. 2. Partial schematic plan view of the TFTR site showing the location of the sitefence, the nearest property lines, and the remote stationary neutron and gamma detectors.

Fig. 3. Neutron dose-equivalent (mrem) versus TFTR DT-neutron measured on the TFTR roof center $(R=0 \mathrm{~m})$ and on the roof at $R=16.8 \mathrm{~m}$ in the northeastward direction. The measured dose-equivalents are directly proportional to neutron source strength.

Fig.4. Log-log plot of neutron and gamma dose-equivalent per TFTR DT-neutron measured versus major radius distance $(\mathrm{m})$ in the northeastward direction toward the nearest property line.

Fig. 5. Measured neutron dose-equivalent at the northeastward site-fence ( $R=125 \mathrm{~m})$ and the property line $(180 \mathrm{~m})$. The measured dose-equivalents are directly proportional to neutron source strength.

Fig. 6. Measured gamma dose-equivalent at the northeastward site-fence ( $R=125 \mathrm{~m})$ and the property line $(180 \mathrm{~m})$. The measured dose-equivalents are directly proportional to neutron source strength.

Fig. 7. Composite total gamma-ray energy spectrum including background for 12 TFTR D-T discharges measured using a high purity Ge gamma spectroscopy system at the northeast site boundary fence detectors at $R=125 \mathrm{~m}$. 
Table 1. Summary of measured neutron and gamma dose-equivalents per TFTR D-T neutron at the outer Test Cell walls.

\begin{tabular}{|c|c|c|c|c|}
\hline Location & $\begin{array}{c}\text { Neutron mrem } \\
\text { per } \\
\text { D-T neutron }\end{array}$ & $\begin{array}{c}\text { Neutron mrem } \\
\text { per } \\
\text { D-D neutron }\end{array}$ & $\begin{array}{c}\text { Gamma mrem } \\
\text { per } \\
\text { D-T neutron }\end{array}$ & $\begin{array}{c}\text { Gamma mrem } \\
\text { per } \\
\text { D-D neutron }\end{array}$ \\
\hline North & $3.2 \pm 0.8 \quad 10-20$ & $1.8 \pm 0.3 E-20$ & $5.3 \pm 1.3 \mathrm{E}-20$ & \\
\hline East & $4.4 \pm 1.1 \mathrm{E}-19$ & & $1.9 \pm 0.5 \mathrm{E}-19$ & $8.9 \pm 2.2 E-20$ \\
\hline South & $1.4 \pm 0.4 E-19$ & $6.9 \pm 1.3 E-21$ & & $5.7 \pm 1.4 \mathrm{E}-19$ \\
\hline West & $9.9 \pm 2.5 E-20$ & $2.7 \pm 0.5 \mathrm{E}-21$ & $1.2 \pm 0.3 E-19$ & $8.5 \pm 1.5$ E-20 \\
\hline Roof Center & $8.6 \pm 2.2$ E-20 & & & \\
\hline $\begin{array}{l}\text { Roof at } \\
R_{N E}=17 \mathrm{~m}\end{array}$ & $3.2 \pm 0.6 \mathrm{E}-20$ & & & \\
\hline
\end{tabular}


Table 2. Summary of measured neutron and gamma dose-equivalents per TFTR D-T neutron at the site-fence and nearest property lines.

\begin{tabular}{|l|l|l|l|l|}
\hline Location & $\begin{array}{c}\text { Neutron mrem } \\
\text { per D-T } n\end{array}$ & $\begin{array}{c}\text { Neutron mrem } \\
\text { per D-D } n\end{array}$ & $\begin{array}{c}\text { Gamma mrem } \\
\text { per D-T } n\end{array}$ & $\begin{array}{c}\text { Gamma mrem } \\
\text { per D-D } n\end{array}$ \\
\hline $\begin{array}{l}\text { NW-Fence } \\
\text { R=125 m }\end{array}$ & $1.2 \pm 0.2 \mathrm{E}-21$ & $2.5 \pm 1.6 \mathrm{E}-22$ & $1.0 \pm 0.2 \mathrm{E}-21$ & $1.1 \pm 0.3 \mathrm{E}-21$ \\
\hline $\begin{array}{l}\text { NE-Fence } \\
\mathrm{R}=125 \mathrm{~m}\end{array}$ & $5.4 \pm 1.0 \mathrm{E}-22$ & $3.2 \pm 0.9 \mathrm{E}-22$ & $3.6 \pm 0.7 \mathrm{E}-22$ & $5.7 \pm 2.7 \mathrm{E}-22$ \\
\hline $\begin{array}{l}\text { SE-Fence } \\
\mathrm{R}=125 \mathrm{~m}\end{array}$ & $4.2 \pm 0.8 \mathrm{E}-22$ & $4.1 \pm 2.1 \mathrm{E}-22$ & $3.9 \pm 0.7 \mathrm{E}-22$ & $3.1 \pm 3.6 \mathrm{E}-22$ \\
\hline $\begin{array}{l}\text { W-Fence } \\
\mathrm{R}=125 \mathrm{~m}\end{array}$ & $1.4 \pm 0.3 \mathrm{E}-21$ & $<3 \mathrm{E}-22$ & $1.6 \pm 0.4 \mathrm{E}-20$ & $8.1 \pm 1.5 \mathrm{E}-21$ \\
\hline $\begin{array}{l}\text { NE- } \\
\text { Property Ln } \\
\text { R=180 m }\end{array}$ & $1.9 \pm 0.4 \mathrm{E}-22$ & $<1.5 \mathrm{E}-22$ & $1.3 \pm 0.2 \mathrm{E}-22$ & $<3 \mathrm{E}-22$ \\
\hline $\begin{array}{l}\text { SE- } \\
\text { Property Ln } \\
\text { R=180 m }\end{array}$ & $1.1 \pm 0.2 \mathrm{E}-22$ & $1.3 \pm 0.8 \mathrm{E}-22$ & $<2 \mathrm{E}-22$ & $<2 \mathrm{E}-22$ \\
\hline
\end{tabular}


Table 3. Summary of contributions to the estimated total dose-equivalent at the nearest property line of 0.73 mrem from Test Cell air activation due to a yield of $1 \mathrm{x}$ 1021 TFTR D-T neutrons.

\begin{tabular}{|l|l|l|l|}
\hline Isotope & Half-life & $\begin{array}{l}\text { Test Cell Activity } \\
\text { (Ci) released per } \\
\text { 1E21 D-T } n\end{array}$ & $\begin{array}{l}\text { Dose-equivalent } \\
\text { at property line } \\
\text { (mrem) }\end{array}$ \\
\hline $13 \mathrm{~N}$ & $10 \mathrm{~min}$ & 63 & 0.18 \\
\hline $41 \mathrm{Ar}$ & $1.8 \mathrm{hr}$ & 85 & 0.34 \\
\hline $16 \mathrm{~N}$ & $7.1 \mathrm{sec}$ & 74 & 0.005 \\
\hline $40 \mathrm{Cl}$ & $80.6 \mathrm{sec}$ & 11 & 0.09 \\
\hline $37 \mathrm{~S}$ & $5 \mathrm{~min}$ & 10 & 0.11 \\
\hline Total & & & 0.73 \\
\hline
\end{tabular}


Table 4. Summary of contributions to the maximum annual dose-equivalent during DT operations at nearest Northeast property line for $1 \times 10^{21}$ TFTR D-T neutrons.

\begin{tabular}{|l|l|l|l|}
\hline Radiation Path & mrem/neutron & $\begin{array}{l}\text { Total } \\
\text { CY 1993 }\end{array}$ & $\begin{array}{l}\text { Total } \\
\text { CY 1994 (est.) }\end{array}$ \\
\hline D-D neutron yield & $7.2 \pm 0.7 \mathrm{E} 18$ & $1 \mathrm{E} 19$ (est.) \\
\hline D-T neutron yield & $1.65 \pm 0.1 \mathrm{E} 19$ & $1 \mathrm{E} 21$ (est.) \\
\hline $\begin{array}{l}\text { Direct n-mrem } \\
\text { from D-D neutrons }\end{array}$ & $<1.5 \mathrm{E}-22$ & $<1.1 \pm 0.1 \mathrm{E}-3$ & $<1.5 \mathrm{E}-3$ \\
\hline $\begin{array}{l}\text { Direct g-mrem } \\
\text { from D-D neutron }\end{array}$ & $<4.1 \pm 2.7 \mathrm{E}-22$ & $3.0 \pm 1.9 \mathrm{E}-3$ & $4.1 \pm 2.7 \mathrm{E}-3$ \\
\hline $\begin{array}{l}\text { Direct n-mrem } \\
\text { from D-T neutrons }\end{array}$ & $1.9 \pm 0.4 \mathrm{E}-22$ & $3.1 \pm 0.7 \mathrm{E}-3$ & $0.19 \pm 0.04$ \\
\hline $\begin{array}{l}\text { Direct g-mrem } \\
\text { from D-T neutrons }\end{array}$ & $1.3 \pm 0.2 \mathrm{E}-22$ & $2.1 \pm 0.3 \mathrm{E}-3$ & $0.13 \pm 0.02$ \\
\hline $\begin{array}{l}\text { Air Activated } \\
\text { by D-D neutrons }\end{array}$ & $3.4 \mathrm{E}-22$ & $2.4 \mathrm{E}-3$ & $3.4 \mathrm{E}-3$ \\
\hline $\begin{array}{l}\text { Air Activated } \\
\text { by D-T neutrons }\end{array}$ & $7.3 \mathrm{E}-22$ & $1.2 \mathrm{E}-2$ & 0.73 \\
\hline $\begin{array}{l}\text { Liquid Nitrogen Activated } \\
\text { by D-T neutrons }\end{array}$ & $2.0 \mathrm{E}-23$ & $3.3 \mathrm{E}-4$ & 0.02 \\
\hline $\begin{array}{l}\text { Normal Tritium Loss } \\
\text { CY 1993 } \\
\text { CY1994 (est.) }\end{array}$ & $\begin{array}{l}2.6 \mathrm{E}-3 \mathrm{mrem} / \mathrm{Ci} \\
<50 \mathrm{Ci} \\
<500 \mathrm{Ci}\end{array}$ & $<0.13$ & $<1.3$ \\
\hline $\begin{array}{l}\text { Annual Property Line } \\
\text { Dose-Equivalent }\end{array}$ & $<0.15$ & $<2.4$ \\
\hline
\end{tabular}




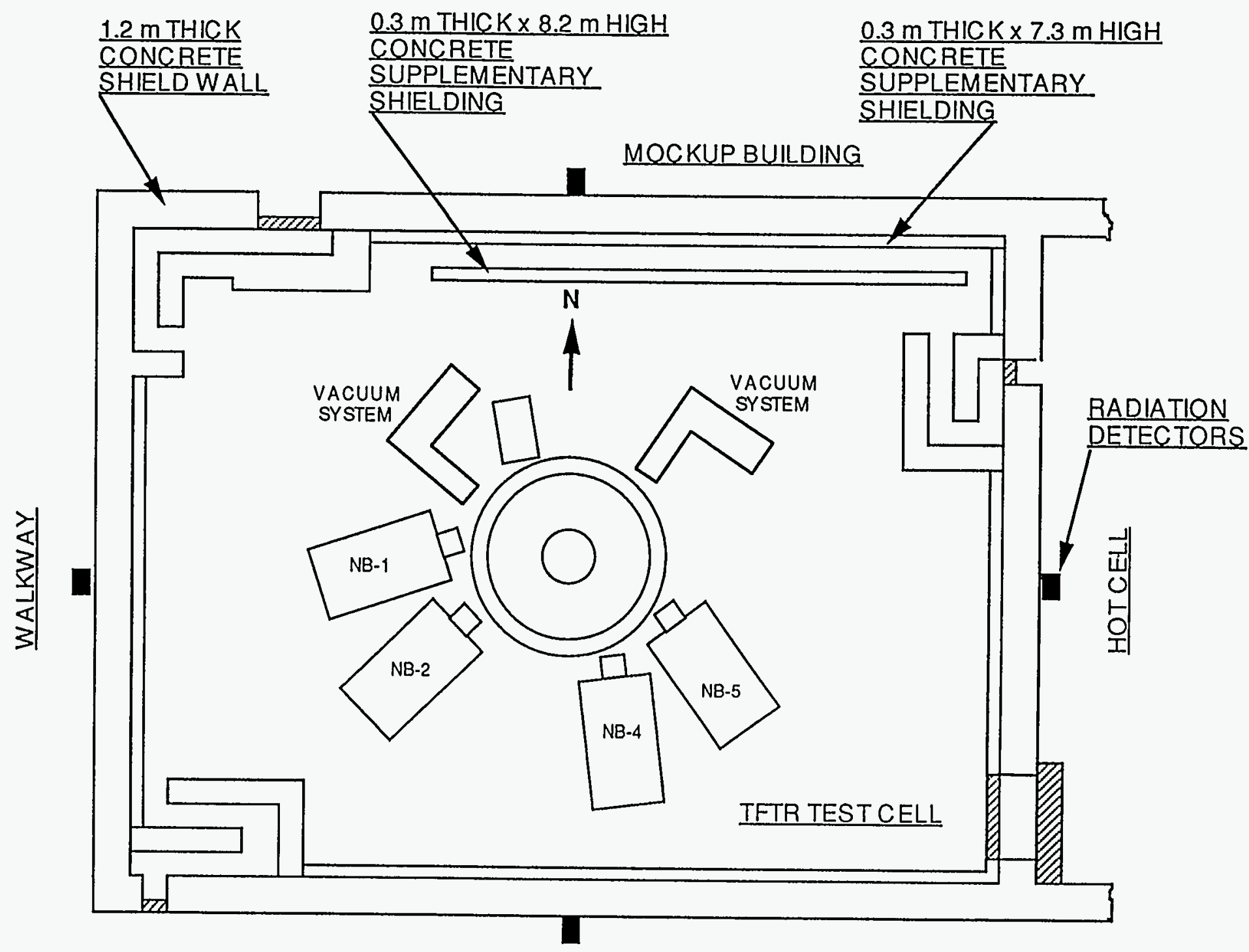




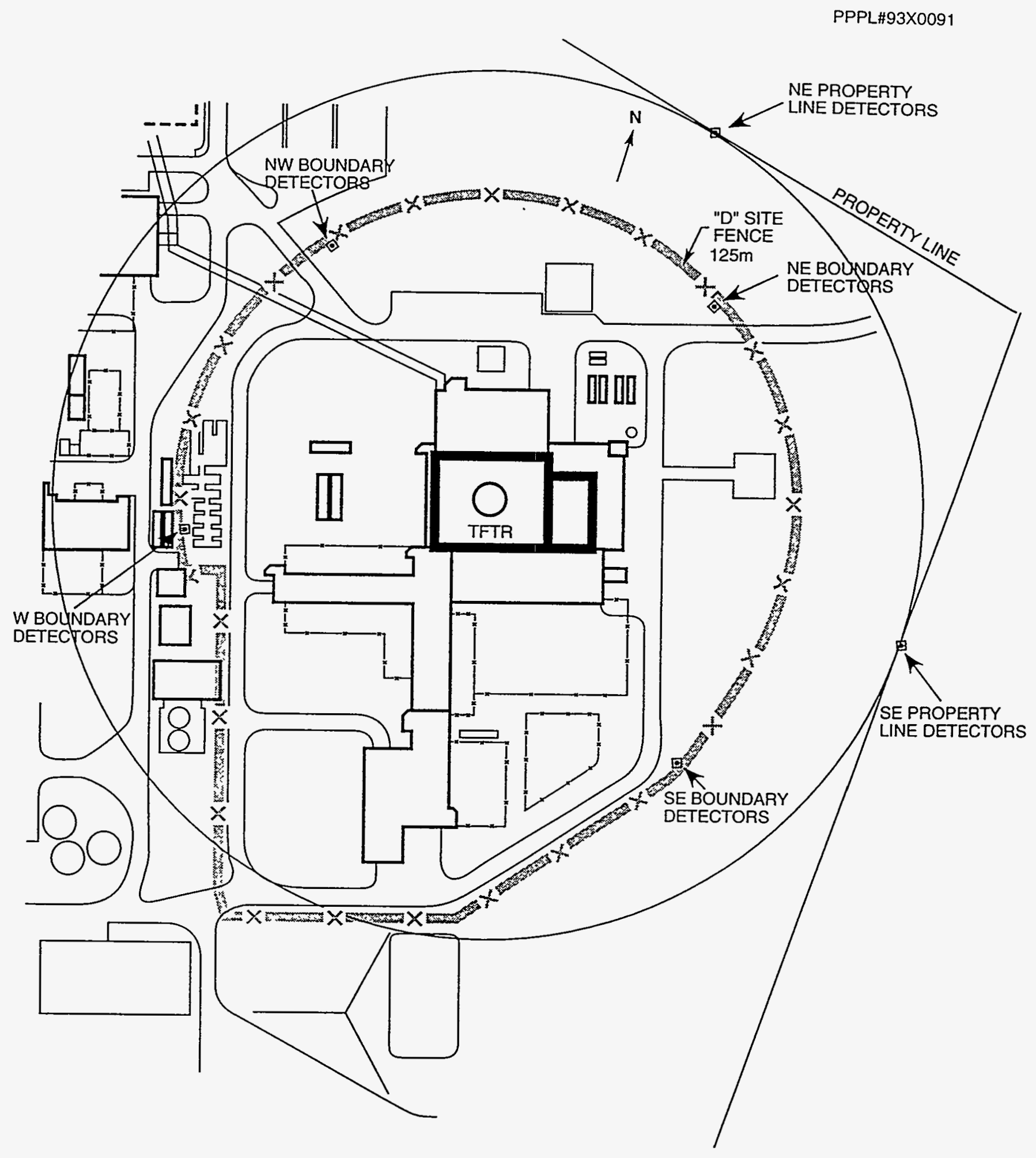

Fig. 2 


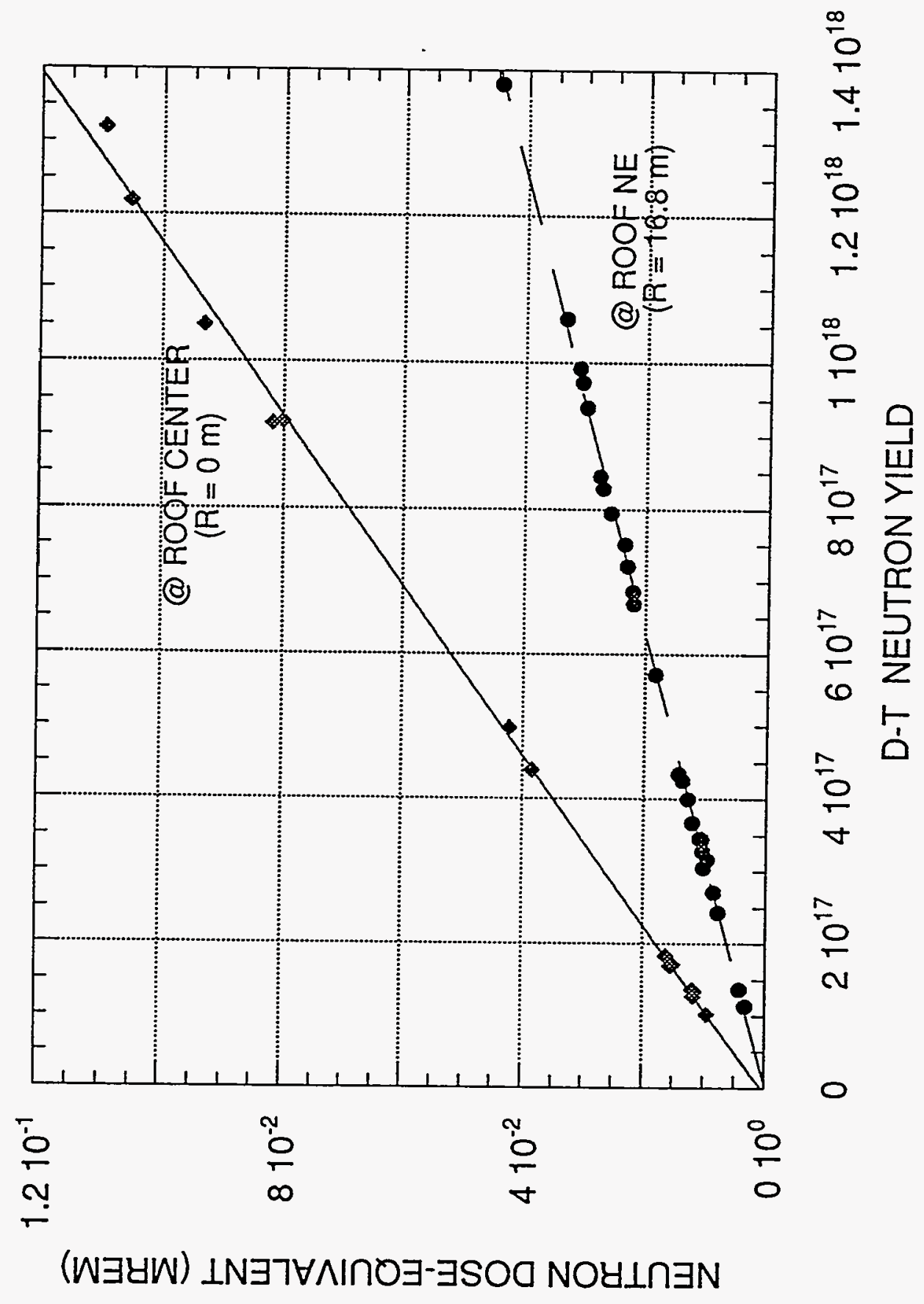


(w) SחIO $\forall y$ YOR $\forall W \perp S \forall \exists H \perp Y O N$

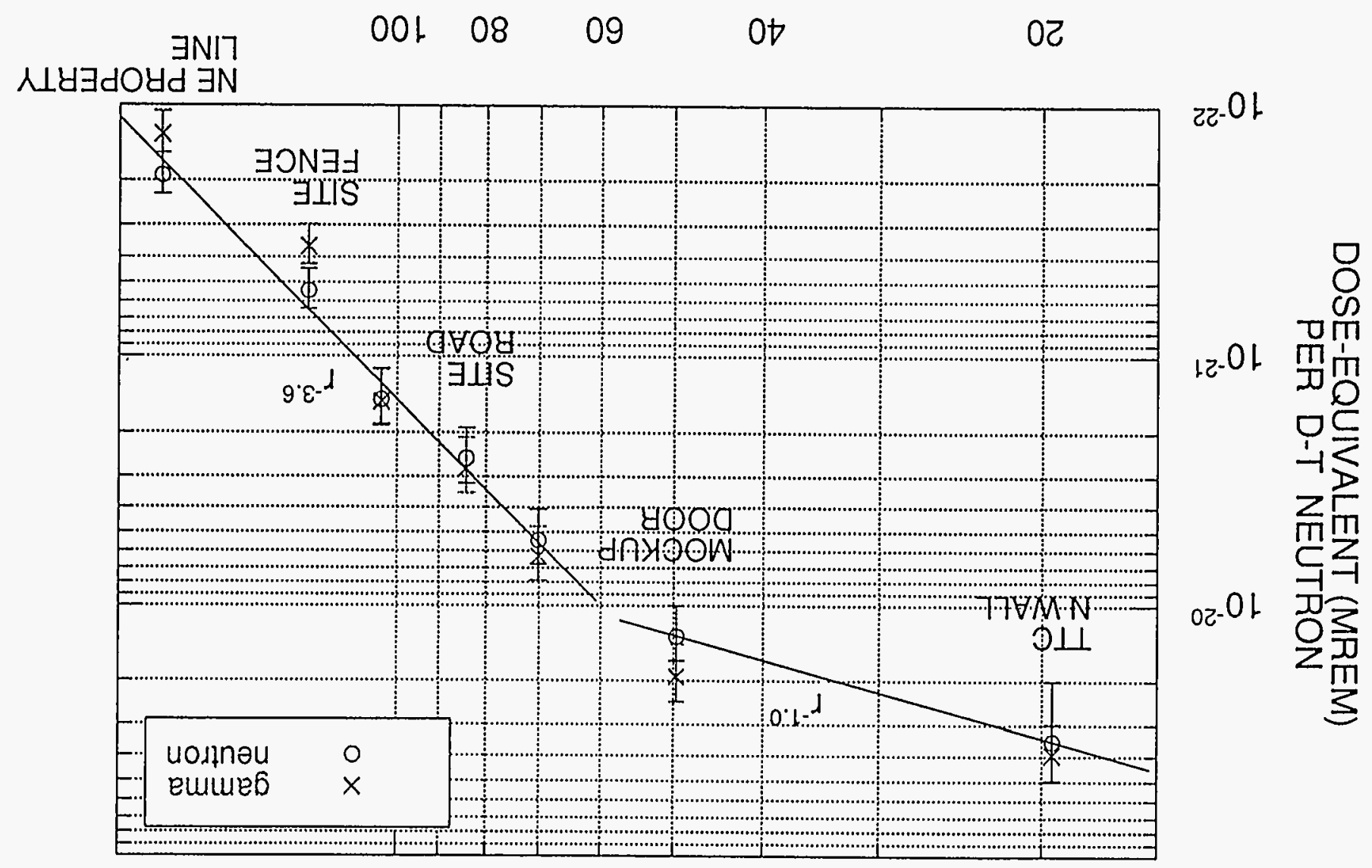




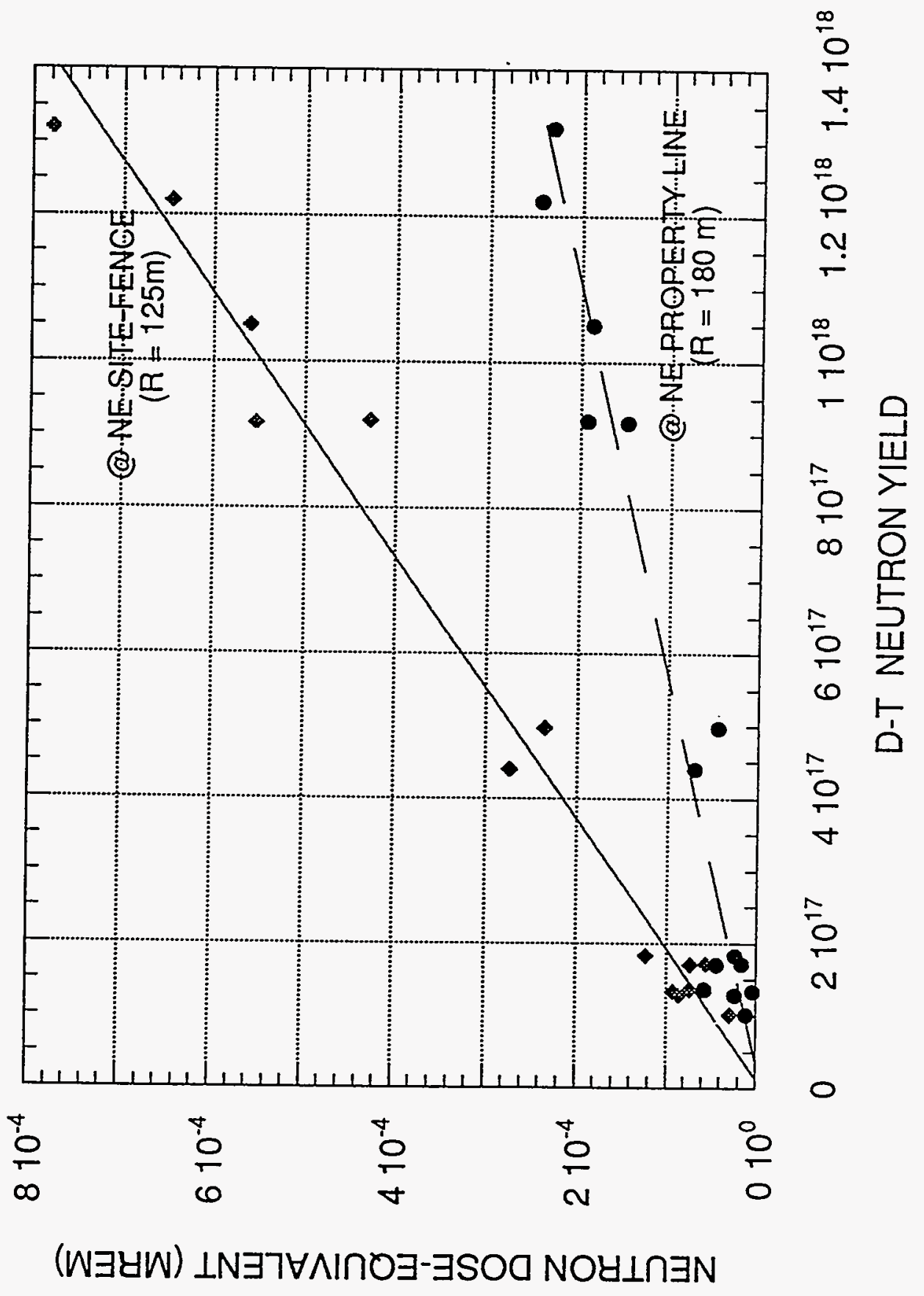




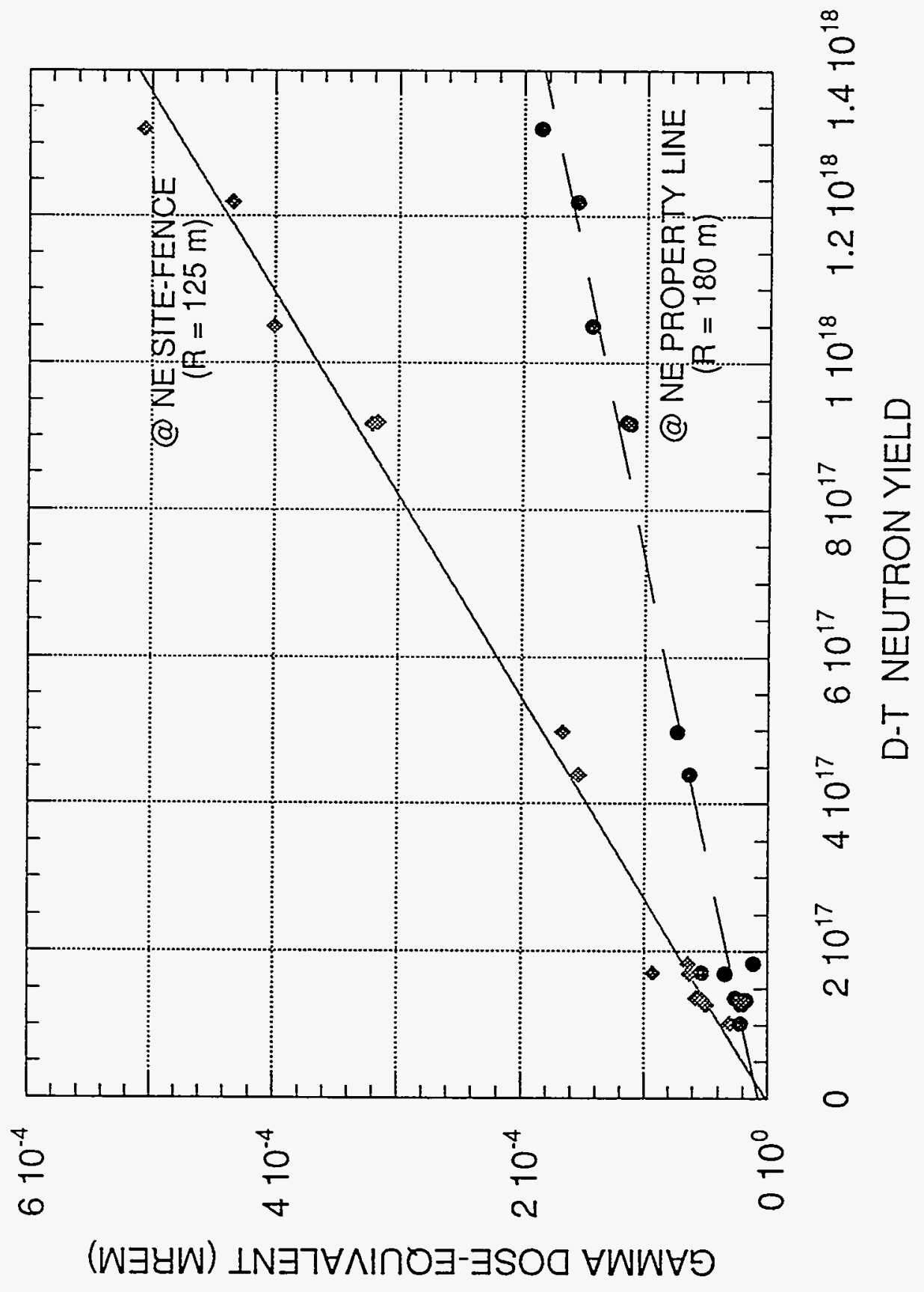




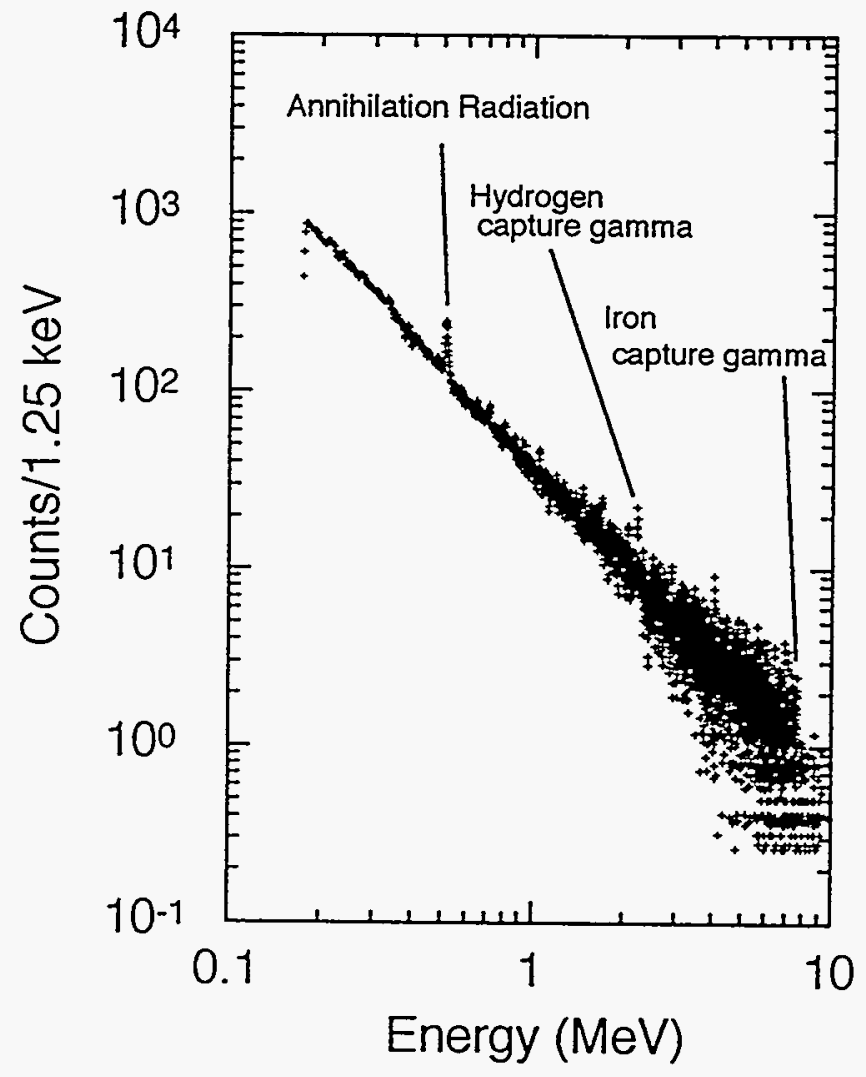

Fig. 7 


\section{EXTERNAL DISTRIBUTION IN ADDITION TO UC-420}

Dr. F. Paoloni, Univ. of Wollongong, AUSTRALIA

Prof. R.C. Cross, Univ. of Sydney, AUSTRALIA

Plasma Research Lab., Australian Nat. Univ., AUSTRALIA

Prof. I.R. Jones, Flinders Univ, AUSTRALIA

Prof. F. Cap, Inst. for Theoretical Physics, AUSTRIA

Prof. M. Heindler, Institut für Theoretische Physik, AUSTRIA

Prof. M. Goossens, Astronomisch Instituut, BELGIUM

Ecole Royale Militaire, Lab. de Phy. Plasmas, BELGIUM

Commission-Europoan, DG. XII-Fusion Prog., BELGIUM

Prof. R. Bouciqué, Rijksuniversiteit Gent, BELGIUM

Dr. P.H. Sakanaka, Instituto Fisica, BRAZIL

Prof. Dr. I.C. Nascimento, Instituto Fisica, Sao Paulo, BRAZIL Instituto Nacional De Pesquisas Espaciais-INPE, BRAZIL

Documents Office, Atomic Energy of Canada Ltd., CANADA

Ms. M. Morin, CCFMTokamak de Varennes, CANADA

Dr. M.P. Bachynski, MPB Technologies, Inc., CANADA

Dr. H.M. Skarsgard, Univ. of Saskatchewan, CANADA

Prof. J. Teichmann, Univ. of Montreal, CANADA

Prof. S.R. Sreenivasan, Univ. of Calgary, CANADA

Prof. R. Marchand, INRS-Energie et Materiaux, CANADA

Dr. R. Bolton, Centre canadien de fusion magnétique, CANADA

Dr. C.R. James, Univ. of Alberta, CANADA

Dr. P. Lukác, Komenského Universzita, CZECHO-SLOVAKIA

The Librarian, Culham Laboratory, ENGLAND

Library, R61, Rutherford Appleton Laboratory, ENGLAND

Mrs. S.A. Hutchinson, JET Library, ENGLAND

Dr. S.C. Sharma, Univ. of South Pacific, FIJI ISLANDS

P. Măhönen, Univ. of Helsinki, FINLAND

Prof. M.N. Bussac, Ecole Polytechnique,, FRANCE

C. Mouttet, Lab. de Physique des Milieux lonisés, FRANCE

J. Radet, CEN/CADARACHE - Bat 506, FRANCE

Prof. E. Economou, Univ. of Crete, GREECE

Ms. C. Rinni, Univ. of loannina, GREECE

Preprint Library, Hungarian Academy of Sci., HUNGARY

Dr. B. DasGupta, Saha Inst. of Nuclear Physics, INDIA

Dr. P. Kaw, Inst. for Plasma Research, INDIA

Dr. P. Rosenau, Israel Inst. of Technology, ISRAEL

Librarian, Intemational Center for Theo Physics, ITALY

Miss C. De Palo, Associazione EURATOM-ENEA, ITALY

Dr. G. Grosso, Istituto di Fisica del Plasma, ITALY

Prof. G. Rostangni, Istituto Gas Ionizzati Del Cnr, ITALY
Dr. H. Yamato, Toshiba Res \& Devel Center, JAPAN

Prof. I. Kawakami, Hiroshima Univ., JAPAN

Prof. K. Nishikawa, Hiroshima Univ., JAPAN

Librarian, Naka Fusion Research Establishment, JAERI, JAPAN

Director, Japan Atomic Energy Research Inst., JAPAN

Prof. S. Itoh, Kyushu Univ., JAPAN

Research Info. Ctr., National Instit. for Fusion Science, JAPAN

Prof. S. Tanaka, Kyoto Univ., JAPAN

Library, Kyoto Univ., JAPAN

Prof. N. Inoue, Univ. of Tokyo, JAPAN

Secretary, Plasma Section, Electrotechnical Lab., JAPAN

Dr. O. Mitarai, Kumamoto Inst. of Technology, JAPAN

Dr. G.S. Lee, Korea Basic Sci. Ctr., KOREA

J. Hyeon-Sook, Korea Atomic Energy Research inst., KOREA

D.I. Choi, The Korea Adv. Inst. of Sci. \& Tech., KOREA

Prof. B.S. Liley, Univ. of Waikato, NEW ZEALAND

Inst of Physics, Chinese Acad Sci PEOPLE'S REP. OF CHINA

Library, Inst. of Plasma Physics, PEOPLE'S REP. OF CHINA

Tsinghua Univ. Library, PEOPLE'S REPUBLIC OF CHINA

Z. Li, S.W. Inst Physics, PEOPLE'S REPUBLIC OF CHINA

Prof. J.A.C. Cabral, Instituto Superior Tecnico, PORTUGAL

Prof. M.A. Hellberg, Univ. of Natal, S. AFRICA

Prof. D.E. Kim, Pohang Inst. of Sci. \& Tech., SO. KOREA

Prof. C.I.E.M.A.T, Fusion Division Library, SPAIN

Dr. L. Stenflo, Univ. of UMEA, SWEDEN

Library, Royal Inst. of Technology, SWEDEN

Prof. H. Wilhelmson, Chalmers Univ. of Tech., SWEDEN

Centre Phys. Des Plasmas, Ecole Polytech, SWITZERLAND

Bibliotheek, Inst. Voor Plasma-Fysica, THE NETHERLANDS

Asst. Prof. Dr. S. Cakir, Middle East Tech. Univ., TURKEY

Dr. V.A. Glukhikh,Sci. Res. Inst. Electrophys.I Apparatus, USSR

Dr. D.D. Ryutov, Siberian Branch of Academy of Sci., USSR

Dr. G.A. Eliseev, I.V. Kurchatov Inst., USSR

Librarian, The Ukr.SSR Academy of Sciences, USSR

Dr. L.M. Kovrizhnykh, Inst. of General Physics, USSA

Kemforschungsanlage $\mathrm{GmbH}$, Zentralbibliothek, W. GERMANY

Bibliothek, Inst. Für Plasmaforschung, W. GERMANY

Prof. K. Schindler, Ruhr-Universitát Bochum, W. GERMANY

Dr. F. Wagner, (ASDEX), Max-Planck-Institut, W. GERMANY

Librarian, Max-Planck-Institut, W. GERMANY 